\title{
Underground Libraries
}

\section{Rolf Fuhlrott}

A number of underground buildings have been constructed during the last two decades, for various reasons: energy conservation, density in the environment of the crowded cities, or preservation of the landscape and historic buildings. Some libraries have also been built below grade. This paper begins with some general remarks on underground buildings followed by the advantages and disadvantages of this new building type. The main part deals with underground libraries, built mainly in the United States, illustrated with photographs and floor plans.

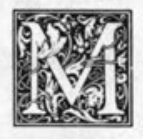

any underground buildings have been constructed during the past two decades. ${ }^{1}$ The reasons are varied: increased efficiency of land use in crowded cities, preservation of open spaces and historic buildings, and energy conservation.

In the recent past certain functions, as a matter of course, were burrowed into the earth, for example, public utilities, technical building equipment, and transport facilities. With the construction of parking garages under squares or beneath municipal parks, new possibilities were offered to town planners. Because a variety of benefits accrue, various types of buildings are now constructed underground. Even library buildings, most of them in the United States, have been built below grade. ${ }^{2}$

\section{TYPES OF UNDERGROUND SPACE}

Many types of underground space exist. They have widely varying characteristics. ${ }^{3}$ One distinction is between mined space and earth-sheltered space. Mined space is usually deeper and thus more isolated from the surface. Mined space has limited points of access: either vertical shafts or horizontal tunnels. Earth-sheltered buildings are built into the soil by surface excavation.
Beyond the general classification of deep-mined and near-surface space, underground buildings can be characterized by their relationship to the surface. Thus, we find subgrade structures totally below grade and invisible, and bermed structures with the floor level only slightly below grade and with earth built up around the buildings, both on the roof and walls. Another type of structure is set into sloping hillside sites, often with on-grade access. In most cases, the berms are used as architectural forms. Examples range from small housing structures to very large multiuse buildings, as well as libraries.

\section{SOME ADVANTAGES}

The fact that underground space provides a degree of isolation from the surface results in a number of benefits for the surface environment as well as for the activities placed underground. Often, an underground building is an appropriate solution for an area with a historical character in which an above-grade structure would be disruptive. This is true on many university campuses where it is important to preserve a quadrangle, square, or mall, for example, Harvard, Yale, or the University of Michigan (Ann Arbor) in the United States; the University of British Columbia in Vancouver, Canada, and the University

Rolf Fuhlrott is library director of the University of Karlsruhe Library, P.O. Box 6920, D-7500 Karlsruhe, Federal Republic of Germany. The author is especially indebted to Harald D. Jones, professor emeritus at Brooklyn College, for his careful reading and criticism of the manuscript. In addition the author also benefited from the advice of David Kaser, professor at Indiana University in Bloomington, who also provided, as well as Harold Jones, some materials inaccessible from Germany. 
of Stellenbosch in South Africa.

In other cases an underground building can preserve the character of sensitive sites where the intrusion of manmade structures may be undesirable, such as Cornell and Princeton universities and Hendrix College (Conway, Arkansas).

By placing a building below grade, the roof can serve as a parking lot or plaza. This is important in built-up areas, for example, the University of Illinois campus at Champaign-Urbana, or in such urban sites as the Walker Community Library in Minneapolis, Minnesota, where it is desirable to preserve open space.

Subsurface structures have some characteristics that contribute to energy efficiency. The greater the percentage or surface area in contact with the earth, the more the structure will benefit, because infiltration is eliminated. This results in both heating and cooling load reduction.

In many climates, the temperature of underground structures may be low. When low or moderate occupancy levels permit, lower temperatures may be appropriate for certain functions, for example, archives and book stacks, where cold storage is good for the stored materials. This technique has been used successfully, for example, in the storage library of the Polytechnic in Zurich, Switzerland.

Of course, when the occupancy of a building grows, it becomes necessary to heat the building within the limits of human comfort. In these cases, it is easy to transfer the existing heat from outside into the underground space. The large mass of earth surrounding the structure modifies the effect of rapid fluctuations in outdoor temperature. Typical day-night or seasonal temperature swings are absent, peak loads are reduced, and the temperature will generally approximate the annual average. This results in smaller requirements for heating and cooling equipment.

Because underground buildings are constructed of long-life materials, primarily concrete, it is assumed that they have a longer life cycle than conventional structures. Another factor contributing to their durability is their protection from temperature variations, freeze-thaw cycles, and winds that damage the roofs and facades of many above-grade buildings.

\section{SOME DISADVANTAGES}

Some of the greatest drawbacks to the use of underground space are not physical or technical in nature, but psychological. However, negative reactions usually diminish or disappear once a well-designed project is in use. Nevertheless, there is a wide range of disadvantages that must be overcome.

One is the lack of natural light and windows providing an outside view. Of course, this is acceptable when the structure is used for stack space and other lowoccupancy functions. In other cases, these problems may be partially overcome by the use of sunken courts, skylights, and other openings to the surface.

Access to underground space is a principal factor in its acceptance. Acceptance of underground buildings is most easily achieved in bermed buildings or those set into sloping sites where direct horizontal entrance from the outside can be provided, such as Bristol, Pennsylvania, public library, Vail (Colorado) Public Library or Saint Meinrad (Indiana) Archabbey Library. For spaces that are not fully below grade, ramps, stairs, and escalators or tunnels from the basements of adjacent buildings can provide access.

Below-grade buildings generally have greater potential for water leakage than above-grade structures. Because the costs associated with water-damage repair are quite high, it is necessary to plan carefully and select a good quality waterproofing system. Such systems will be more expensive for underground than for aboveground structures.

An indoor water problem can be caused by condensation. Condensation on indoor surfaces may occur because the surrounding earth is generally cooler than the indoor air temperature. This situation can be prevented by adequate insulation or mechanical dehumidification.

\section{SOME PSYCHOLOGICAL CONSIDERATIONS}

The lack of natural light is one of the most frequently criticized characteristics 
of underground space. The difficulty of orientation in windowless rooms can result in a number of negative psychological reactions. However, through the use of sloping sites, courtyards, or skylights, natural light and an exterior view often can be provided.

Negative reactions to windowless space appear related to a fear of structural collapse and subsequent burial, or a fear of being trapped in windowless buildings. Closely related to the general fear of being underground is claustrophobia, the fear of small, enclosed spaces with limited escape routes. These fears may be exacerbated in spaces that are not only windowless, but noiseless. A totally silent environment may be unnerving and cause a concern for privacy in conversations.

\section{SOME DESIGN CONSIDERATIONS}

Many of these negative effects may be compensated for through proper design. Greater advantage may be obtained if the structure is not placed completely below grade. Through cuts into sloping sites at Cornell, Saint Meinrad, and Vail, and through the construction of above-ground superstructures at Bristol and the University of Illinois it has been possible to highlight the entrance and provide openings for natural light.

A site with sufficient slope provides design opportunities not available on a flat site. Thus, very often a portion of a building is placed above ground with earth bermed around it. Of course, berms represent an additional object on the landscape and diminish the unobtrustiveness of the structure (Hendrix, Harvard). When a building is partially exposed, the berms and extensive landscaping can be used to create forms on the site that draw attention. If the building is placed completely beneath the surface there is the need for a clear understanding of the building size (University of Michigan, for example), location, and entry. Sometimes a plaza, forming the roof of an underground structure, can define the underground building as at Walker Library in Minneapolis. In a more open site, these aims are usually best accomplished by the use of grade changes, such as at Harvard, paving pat- terns, trees, shrubs and variations in groundcover, along with retaining walls and other elements as at Stellenbosch and the University of Illinois.

The manner in which an underground structure may be entered can have an important influence on the user's perception of the building. The entrance, serving as the transition from the exterior to the interior, is a key element in orienting and directing people to the functional spaces inside. Viewed from the exterior, the entrance may be the dominant image of a building. In order to minimize negative reactions, entrances may be created that are similar to those in conventional abovegrade constructions (Bristol, Walker, University of Illinois). This may involve designing an entrance at existing grade that does not require descending stairs. In many instances, underground structures are additions to existing above-grade buildings. Here, some of these entry design problems are minimized, because the main entrance occurs through the conventional building (University of Michigan, UCLA, Oxford, Yale).

The entry often serves as a major area for the provision of natural light and exterior view. The degree to which this is necessary or even desirable depends upon the specific function of the building. The techniques selected for introducing natural light and view are influenced not only by functional space needs, but also by the site and the size of the structure. On a sloping site, conventional vertical glazing can be used for the spaces on one side of the building (Cornell). If earth berms are placed around a structure on a flat site, conventional vertical glazing can be provided on the building's perimeter by creating openings in the berms (Harvard). Natural light and view can be provided through the creation of courtyards (Harvard, University of Illinois). Skylights are a common means of introducing natural light on flat sites (Stellenbosch). But skylights alone may not be an adequate substitute for conventional windows.

In recent years, novel techniques have been developed to provide or enhance the effect of natural light and view in underground structures. Mirrors may be used to 
reflect light into spaces not immediately adjacent to exterior openings (Walker Library). Another, perhaps less satisfactory, approach is to provide an exterior view by using mirrors or lenses in a manner similar to that of a periscope (University of Michigan). These various optical techniques, however mechanistic, do permit greater design flexibility in underground structures.

In addition to the normal concern for creating attractive interior environments, special attention must be paid to offsetting the patently negative psychological effects of underground structures. A number of techniques are used to provide visual stimuli and create a feeling of spaciousness. Wider corridors and higher than usual ceilings, together with open-plan layouts using low or glass partitions, are simple means of creating the impression of space. Even more effective is the use of large, multilevel central spaces or atriums. Balconies that overlook large open spaces can diminish the sensation of being below grade (University of Michigan). These techniques also give users points of reference to help offset disorientation (Stellenbosch). In buildings with interior courtyards or central spaces, planters and fountains can create the impression of being out-of-doors.

\section{EXAMPLES OF UNDERGROUND LIBRARIES}

Burying library buildings below grade was not a sudden innovation, but a slow development. First, stacks were placed in basement areas. Later, below-grade floors were added. This aim was best accomplished by using grade changes and building wings as at the Firestone Library of Princeton in 1949.

In the early sixties, three libraries placed primary functional areas below grade. In 1962 , half of the space devoted to public services at the John M. Olin Library, Washington University, St. Louis, Missouri, was relocated in two underground levels. ${ }^{4}$ An atrium placed near the front of the building provides exterior light to the reading rooms. This atrium is regarded as an excellent example of the merging of beauty and utility.
This example was followed in 1963 by the Beinecke Rare Book and Manuscript Library at Yale. ${ }^{5}$ The Beinecke Library, on the southwest corner of the historical Hewitt Quadrangle, was built on the last piece of uncommitted ground in the central area of the university. The existing quadrangle restricted the mass of the building that the architects, Skidmore, Owings and Merrill, might construct at this location. The architects also faced the problem of excluding sunlight and controlling temperature and humidity to protect the rare books to be stored in the structure. This problem was solved by burying the library two levels below grade, leaving only the well-known exhibition hall above ground.

A paved plaza connects all surrounding buildings. The control desk, catalogs, technical service areas, and a reading room are clustered around a sunken court on the main lower level. Two tunnels connect these spaces with the Sterling Memorial Library and the Law Library.

The third major underground library construction project of the sixties, the Eisenhower Library at Johns Hopkins University, was completed in November $1964 .^{6}$ Approximately 75 percent of the bulk of the Eisenhower Library was placed below ground. Only one and one-half of its six floors are visible from Charles Street. From there, an observer looks up past a pleasantly graded, landscaped slope to the library, its Georgian exterior complementing neighboring buildings. Below the modest upper structure are four and one-half larger floors, each measuring 292 by 110 feet, that benefit on the south side from sunlight admitted by a natural 30 -foot depression. It is here that the reading rooms on the main floor are located, the southern wall of the reading area largely composed of windows and glass doors that lead to an open-air reading terrace. The building is fully air-conditioned. The lighting is largely, but not entirely, fluorescent.

Large sections of underground space are located beneath high-rise library buildings. In order to consolidate departmental science libraries under a single roof at Brown University in Providence, Rhode 
Island, the architects, Warner, Burns, Toan and Lunde, in 1966, designed the sixteen-story Science Library as a visual reference point and symbol for the university's science complex. To preserve the impact of the tower rising straight from the ground, the architects put the largest and busiest space underground. The 25,000-square-foot lower level, which covers five times the area of one tower level, contains the main working library floor. It is dropped below a podium that is skylit at both ends. Sunken courts at the four corners of the tower offer additional daylight and a landscaped view for the underground interiors.

In 1973, the twenty-eight level, 110-by110-foot library structure at the University of Massachusetts, Amherst, was placed on a two-level podium of 228 by 324 feet. Two staircases lead from the entrance level down to the main floor where the office, reading rooms, and public and technical services are located around a sunken court that lights these spaces. The two underground levels have been built into a sloping site. The lower level receives light from the side and offers a view of the beautiful campus lake.

Also placed into a slope is the Bristol, Pennsylvania, public library. ${ }^{7}$ The Margaret R. Grundy Memorial Library, located along the lower Delaware River in the historic district of Bristol, opened in June 1966. By placing the bulk of the building into a bank, the architects, Carroll, Grisdale and Partners of Philadelphia, preserved the residential scale of the neighborhood and accommodated the structure to the change of levels from the street above to the riverside terrace. Visitors enter from the street level through an abovegrade glass-enclosed pavilion, which encloses a stairway, an elevator, and a balcony. The lawn-covered roof offers open vistas of the river and the garden, including a public sidewalk of red brick. Descending the steps into the library, visitors look out on a garden through the exposed side of solid-glass windows and doors. The library, which is 250 feet long by 75 feet wide, covers approximately 15,000 square feet. It has a shelving capacity of 55,000 volumes and seating for fifty.
Because the the building is constructed of poured concrete with vinyl floors and glass walls covering two sides, there are problems with noise, temperature control, and humidity. Water leaks occurred in the roof of the above-ground entrance structure as well as in the concrete ceiling that is under the irrigated lawn. The entrance roof has been replaced and the librarians hope that the two large areas on either side of the entrance will be replaced in the next few years.

The first library to be built completely underground was constructed in 1967 in Conway, Arkansas. ${ }^{8}$ Because the preservation of the integrity of the site was a concern, no one at Hendrix College wanted to place the new Bailey Library on the school's flat, open mall. The problem was resolved in 1967 by architect Philip Johnson of New York City, in collaboration with Joe Lambert, landscape architect of Dallas. Johnson and Lambert's solution was a two-story subgrade library under the mall, already the focus of campus activity.

Hendrix planners carved out a large sunken plaza to serve as the approach to the library's first-floor entrance. Earth removed from the plaza was used to bank the library structure and to create mounds, hillocks, and undulations on the formerly flat mall that now includes terraces and a fountain, cascading continuously into a pool. The top of the library is a conversation piece. It is a brick-paved patio with planters large enough to accommodate trees and shrubs.

A series of gardens were created at different levels and a visitor may descend to the upper floor of the library without the feeling of entering a basement. The feeling of spaciousness, created outside, is intensified upon entering the library. Because daylight is absent, and to offset the psychological effect of entering the earth, the library's lighting is considerably brighter than usual. This gives the Bailey Library an uncloistered feeling.

The Bailey Library, with approximately 32,000 feet of gross floor space, will accommodate 115,000 volumes and 420 seating spaces, including 240 individual carrels. Happily, the library does not need a 


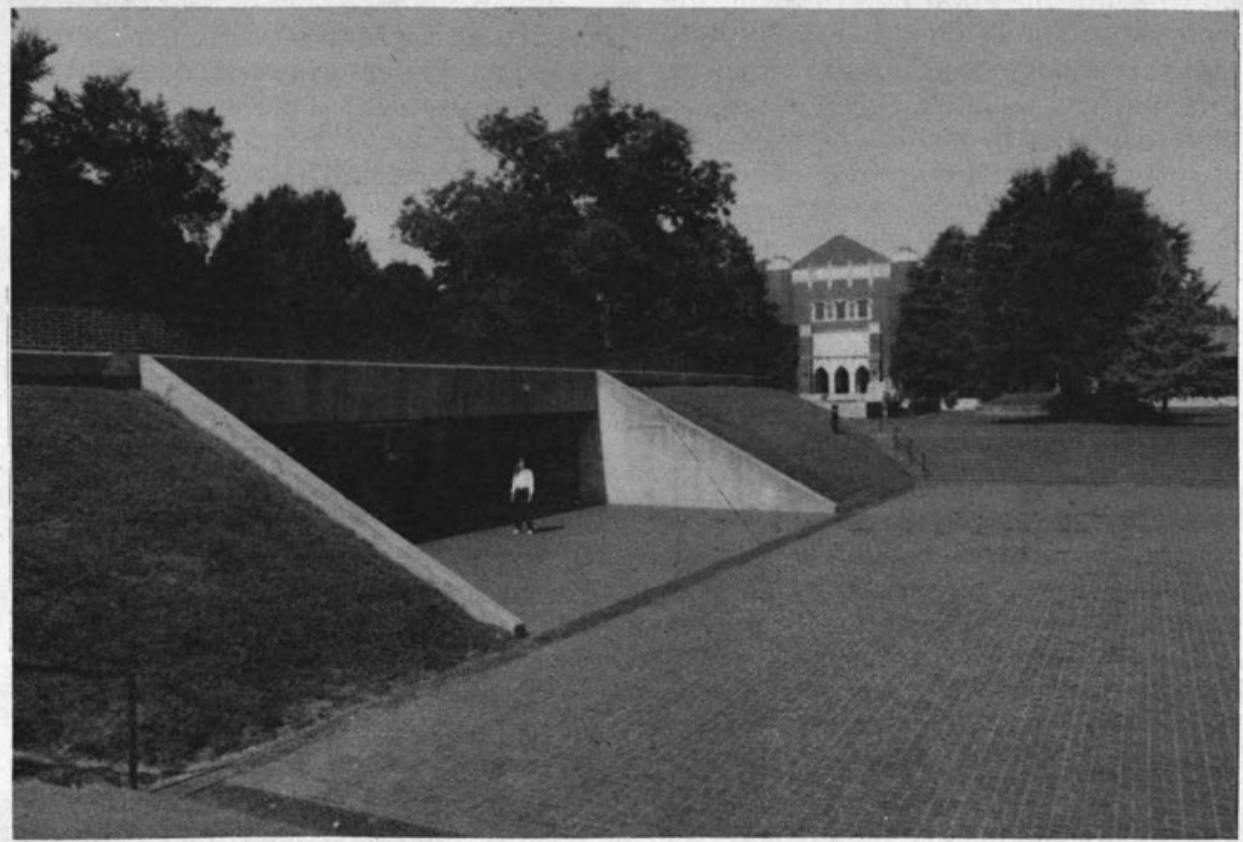

Hendrix College in Conway, Arkansas: Large sunken plaza is the approach to library's entrance. Earth removed from the plaza was used to bank library and landscape mall.

heating plant because the earth is a good insulator. Even in winter, light and body heat are the only heat sources the library requires. Also, air conditioning is less expensive to operate due to earth insulation-as much as 35 percent less than would be required for an aboveground structure. Unfortunately, with the first heavy rains of fall 1967, the Bailey Library leaked. For more than fifteen years, leakage has remained a problem. On the other hand, the library provided a link between Hendrix College and the residents of the county when many citizens sought refuge in the underground structure during storms and tornado warnings!

Stately architecture and aging books prompted the University of California at Los Angeles to extend the underground portion of its Clark Memorial Library. 'The library, located ten miles from campus in Los Angeles's Crenshaw District, is a research facility constructed, in 1926, in Italian Renaissance style. It is stocked with 70,000 rare books and 5,000 manuscripts. In 1951, the library added a block of under- ground stacks by extending its basement. In 1968, the architectural firm of Cordes and Crosby, Los Angeles, pushed this extension still further, under the library's front lawn. The underground structure is ideal for preserving the library's old books and papers because the temperature and humidity are easily controlled. Just thirty inches of earth lie atop the library. To waterproof the structure, layers of coal-tar saturated felt and cotton fabric were wrapped around it, with alternate moppings of coal-tar waterproofing pitch. Underfloor drainage channels were installed to remove ground water. Made of reinforced concrete, the building provides approximately 4,500 square feet of floor space. Besides 2,070 square feet of stack area, the addition provides researchers with ten studies, a lounge, a kitchenette, and restrooms.

In June 1969, the new University of Illinois Undergraduate Library at UrbanaChampaign was dedicated. ${ }^{10}$ The University lies between Urbana and Champaign with its major axis of development in a 
north-south direction described by the main mall. The campus is mostly organized around the liberal arts and sciences core, the nucleus of which is the General Library, housed in a building constructed in 1930. Because the number of undergraduates had grown to 24,000 , it became necessary to enlarge the library. The site chosen was directly east of the existing structure, which was central in relation to undergraduate classrooms and residence halls.

The architects, Richardson and Associates of Champaign, and Urbana's planners had two reasons for putting the new library underground. First, they wished to maintain the open appearance of the mall. Second, they had vetoed a normal aboveground structure because it would have shaded the nearby Morrow Plots, the oldest agricultural experiment fields in the United States.

The new library is of modular design with maximum flexibility of space. It consists of two floors approximately 217 by 241 feet with a 72 -foot square sunken court. A tunnel connects the upper level with the basement of the General Library building. The grade level is conceived as a landscaped, lighted plaza. Bench seating is integrated into large, tree-size planting tubs on the plaza. The red-brick pavilions, located on the east and west sides, give access to stairways, elevators, and dumbwaiters. These pavilions are designed to give definition to the building entrances as well as to provide an edge to the plaza and to heighten its aesthetic effect.

All feeling of being underground disappears as soon as one descends to the first level. Each level is square with a courtyard in the middle opening up to the stone plaza and sky above. The courtyard is accessible from the lower level to provide controlled outdoor reading space in fair weather. The walls enclosing the court on each level are made of glass so that the view into the light and grassy landscape of the court gives the impression of being above ground.

Approximately two-thirds of the library's 1,905 seats are individual study

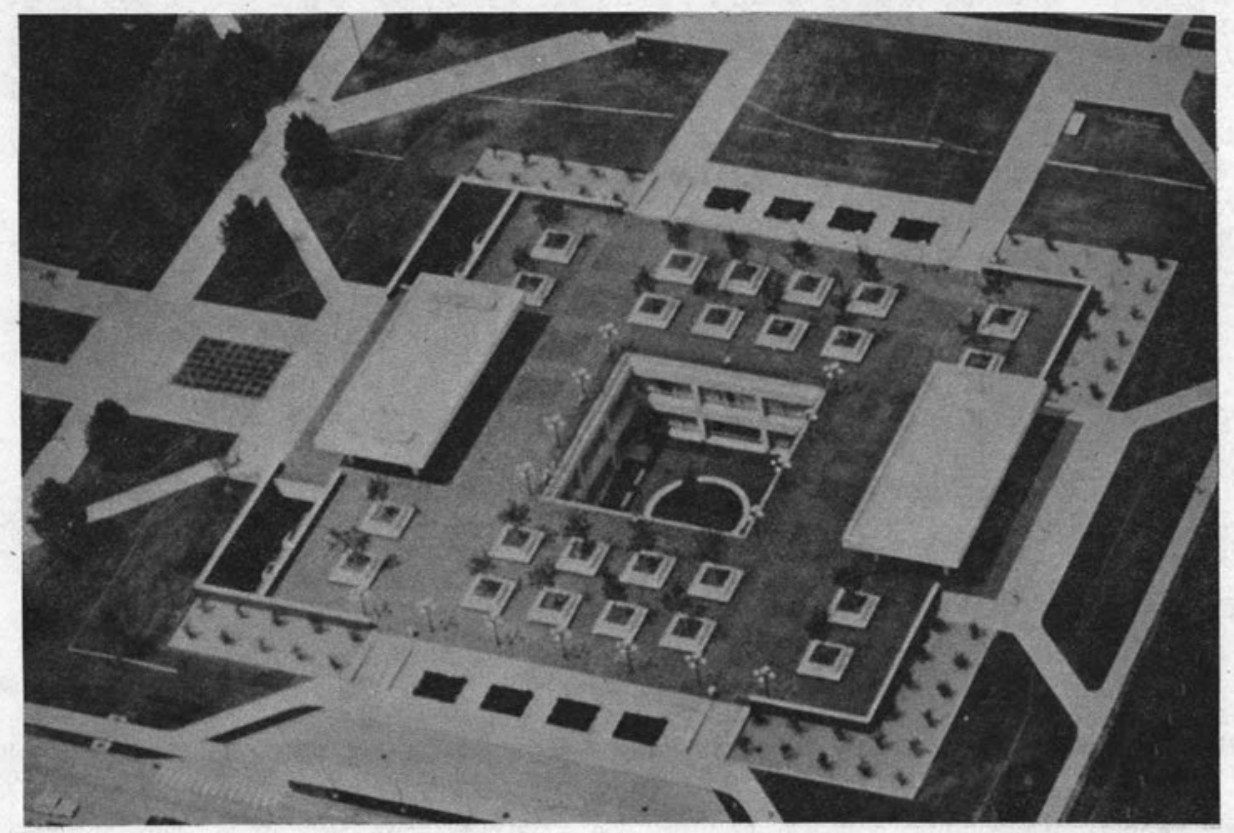

University of Illinois-Urbana-Champaign: View of the broad plaza, which forms the top of the Undergraduate Library, with two entrance pavillions and the sunken court. 


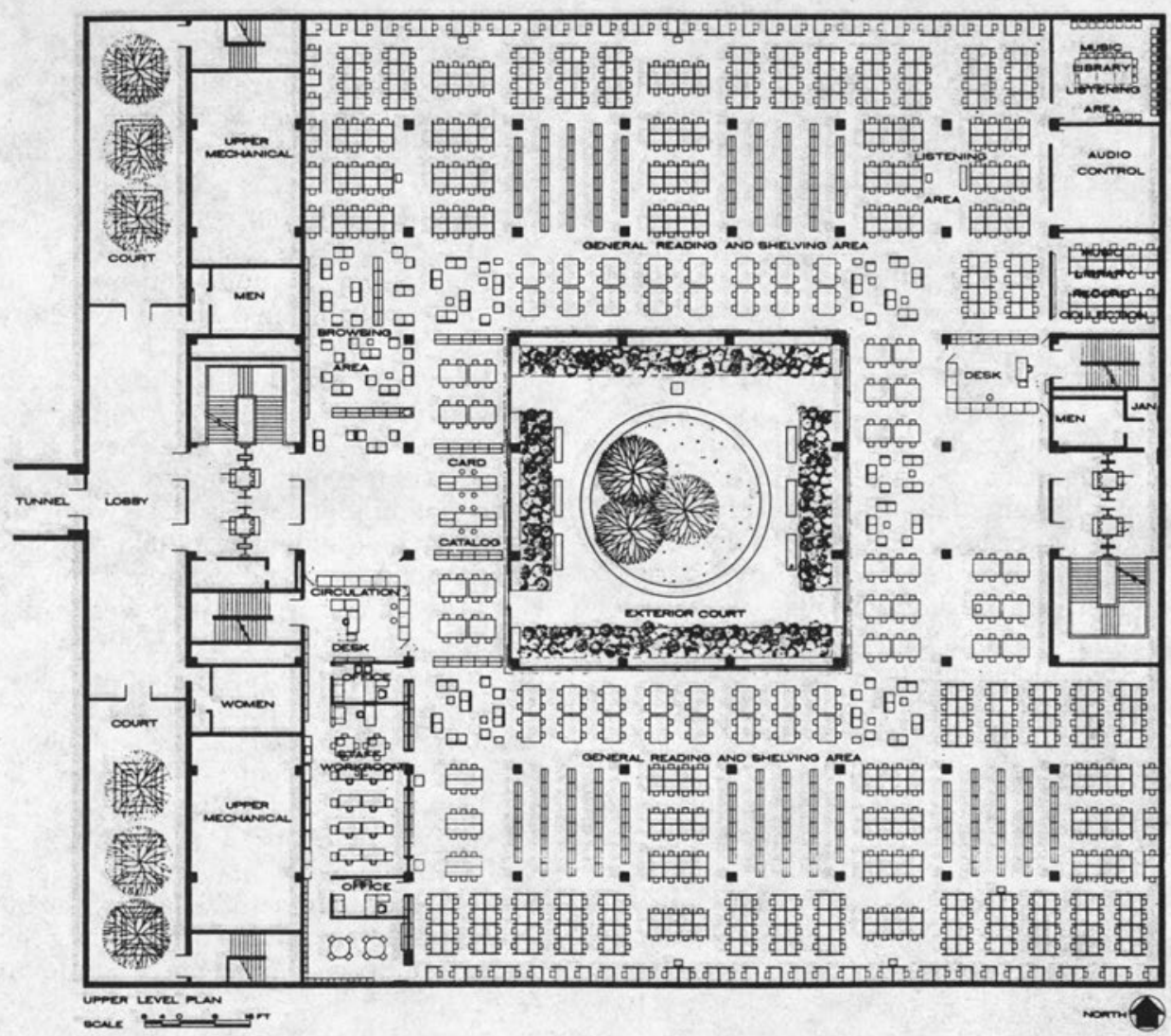

University of Illinois Undergraduate Library: Floor plan of the upper level with tunnel at left leading from the main library building.

carrels that provide as much privacy as can be arranged in the unpartitioned areas. There is book space for 150,000 volumes. If there is a need for more shelving space, the structural system is designed to permit expansion to the north and south. Ultimately, the facility can be doubled in size.

The entire building is air-conditioned. A general lighting intensity of ninety footcandles is specified in both reading and shelving areas. Wall-to-wall carpeting and acoustical ceilings are provided throughout in order to assure maximum quiet.

It is said that this library is designed more for people than for books and, indeed, the Illinois Undergraduate Library has won several architectural awards.
Nevertheless, some severe water conditions had to be dealt with. Because the building is below the water table, it was to be constructed as a concrete boat. Rain and melting snow are taken off by a sump pump system. In the event of failure, an auxiliary generator assures power.

In January 1971, the underground addition to the Sterling Memorial Library at Yale University in New Haven was opened. ${ }^{11}$ The two-level facility, designed by Edward Larrebee Barnes of New Haven, has been built directly across from Sterling's main entrance beneath the Cross Campus Green, a popular place for student relaxation. To save this precious large green area, the Cross Campus Library was built underground, connected 
to Sterling by a tunnel beneath High Street.

With a capacity of 225,000 volumes, the Cross Campus Library is operated as a part of Sterling for intensive use of books under heavy demand by undergraduates, graduate students, and faculty. The Cross Campus building was designed to provide greatest flexibility, allowing juxtaposition of readers and books. Seats are available for 750 readers. The air-conditioned facility is rectangular, measuring 223 by 140 feet.

The route from Sterling passes through a student lounge and leads directly toward the circulation desk on the addition's upper level. On either side of the tunnel entrance, two 30-by-32-foot sunken courts allow an alternate access route from High Street when Sterling is closed, and simultaneously provide some measure of daylight in the subterranean building. Unfortunately, these courts suffer from frequent water leaks around the perimeters. Two enlarged emergency exits at the other end let in additional light. The color of all painted surfaces, furniture, and equipment has been coordinated with the lighting to assure uniform illumination without glare or distracting contrasts.

A classic space problem arose in Canada in 1972 when the University of British Columbia at Vancouver faced the need for more library space. The new structure needed to be located as near as possible to the Main Library, but could not destroy the university's oak-lined pedestrian mall. ${ }^{12}$ Architects Rhone and Iredale of Vancouver determined that a two-story building for the Sedgewick Undergraduate Library could exist under the main mall, as this ran past the existing library about twelve feet higher than the main library entrance. On the opposite side, an eight-foot differential existed between the mall and the Mathematics Building. This was the chance for landscape gardening of two terraced courts. East and west exposures open onto these courts, with precast planters overhanging glazed window walls. Pedestrians could use the mall as usual, with no grade changes and, about twelve feet below, both old and new libraries could share the same entry level.

Two truncated cones that rise from the mall form skylights that provide views into the library and natural light for the internal spiral staircase. Before reaching the cones, a stairway at either end leads down

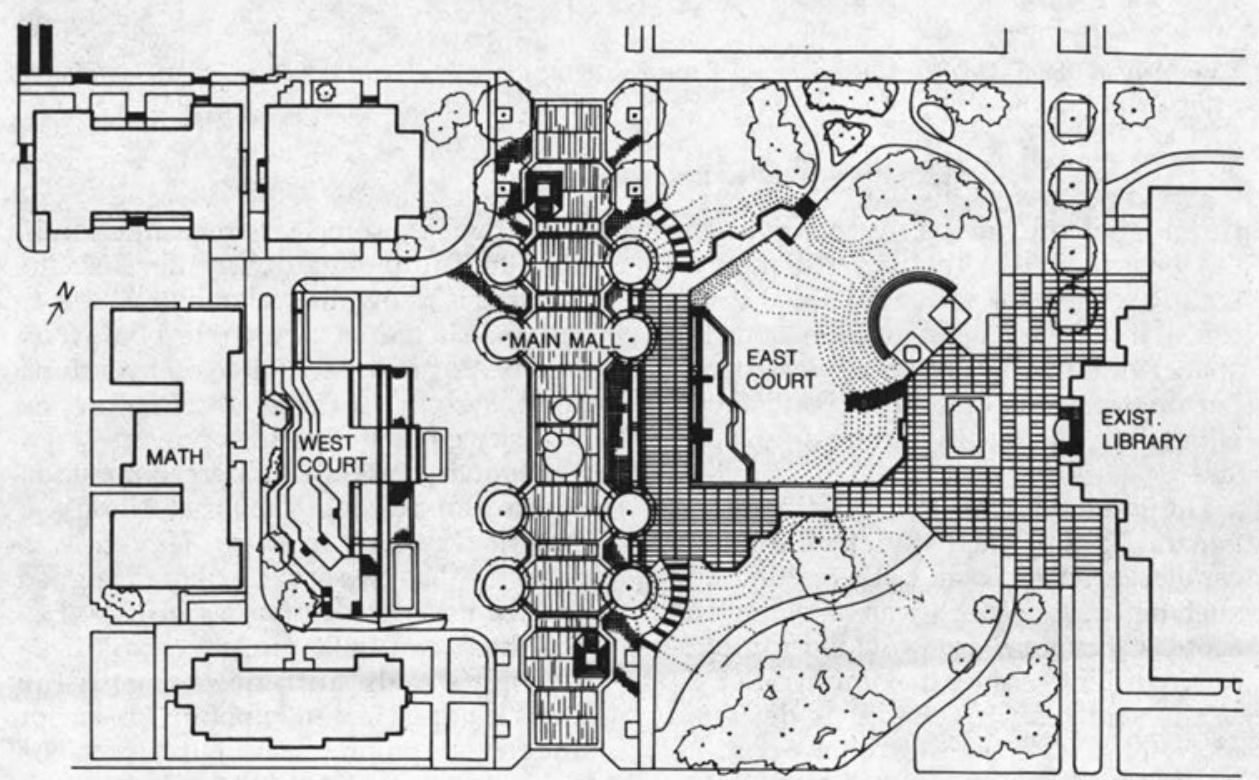

Sedgewick Undergraduate Library in Vancouver: Site plan with the main mall above the library. 
Sedgewick Undergraduate Library in Vancouver: Floor plan of the upper level with the main entry and the eight drums for the oak trees flanking the mall.
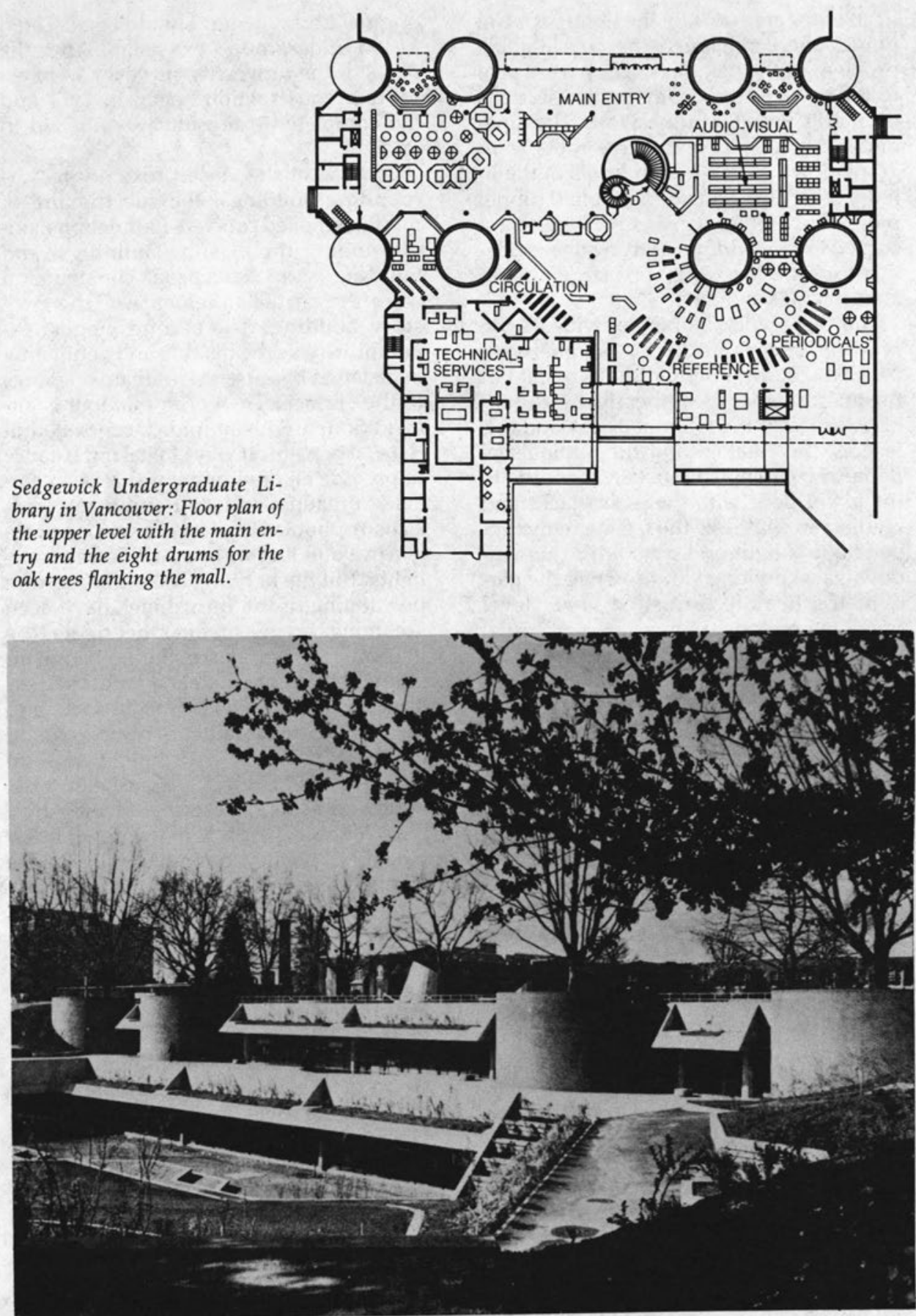

Sedgewick Undergraduate Library in Vancouver: View of the main entrance facade and the landscaped east court with the oak trees in the drums flanking the mall. 
to an entry area outside the library control point. There remained the considerable problem of the oak trees. They were protected by high steel drums built of sections ordinarily used for tunnel work. The ninemeter drums encase the tree roots from grade down through both levels of the library structure. Outside the bolted tunnel plate is an air space, insulation, and a curved brick cladding, a strong design element interrupting the very large area of about 113,000 square feet.

The Sedgewick Library provides 1,646 reading spaces and has a capacity of 200,000 volumes. Behind the turnstiles at the main entry of the upper floor is the circulation desk, the reference desk and collection, the catalog, and the audiovisual department. The spiral staircase leads to the lower floor with the main stacks and reading areas. While the feeling of the upper floor is light and airy, with the window walls' inviting view down to the garden, the heavily furnished lower level finds its greatest use in a range of visual activities.

Sedgewick Library is an excellent example of how solutions to underground building problems can be found. It won the 1972 Award of the Canadian Architecture Yearbook, and the 1973 First Award of the Royal Architectural Institute of Canada, the highest architectural award in Canada, in a competition that includes all types of buildings.

In 1975 , one of the largest scientific libraries in the United Kingdom, the Radcliffe Science Library, Oxford, England, constructed an underground extension that is believed to be the largest belowground library space of any British library. ${ }^{13}$ The original library in the Radcliffe Campus opened in 1749 . In 1861, the collection was brought to the University $\mathrm{Mu}$ seum. Because of the rapid expansion of natural science literature, it was necessary to construct, in 1901 and 1934, the two wings of the present library. The holdings grew more rapidly when the library was incorporated into the Bodleian Library in 1927. The library's shelving was filled by the early 1960 s. In 1968 , the decision was made that the area to the west of the University Museum, partly embraced by the original library wings should be allocated for an underground extension. After the plans of the university surveyor were accepted, construction began in 1971 and the completed extension was opened in 1975.

Because of the close proximity to surrounding buildings, the substructure of reinforced piled concrete foundations, underpinning the existing buildings, and building with waterproof construction were the costliest elements of the twostory building. The second biggest expenditure was the heating and ventilating installation because there are no openings to the surface. The entire building is airconditioned with humidity controlled at 50 to 60 percent. It was of vital importance to provide an environment that is acceptable to readers and staff and that avoids claustrophobia. The last is a serious problem in a building without windows or skylights. But the lighting, color scheme, and positioning of the furnishings have been accomplished in a manner that creates the illusion of greater space. Sound is well insulated from the exterior and the low background noise level was distracting to the staff. Consideration is being given to the introduction of background noise to raise the sound level. Nevertheless, the subdued atmosphere is welcomed by most of the 260 readers in the upper level, which has a capacity of 190,000 volumes for the physical sciences. The lower level contains mobile high density storage units for 570,000 volumes. The gross floor area of both levels is about 46,000 square feet.

In 1976, the Harvard University Library at Cambridge, the largest university library in the world, opened the Nathan Marsh Pusey Library, an underground addition to its Harvard College Library. ${ }^{14} \mathrm{Of}$ the eight libraries constituting the College Library, three required their own reading rooms and better conservation of their priceless collections. These were the Harvard Theatre Collection, the Harvard University Archives and the Harvard Map Collection. The main problem faced by the designers was how to tuck a building unobtrusively into one of the few remaining open spaces on the crowded, busy site of Harvard Yard, a site of great historic inter- 


\section{PUSEY LIBRARY, LEVEL P1}

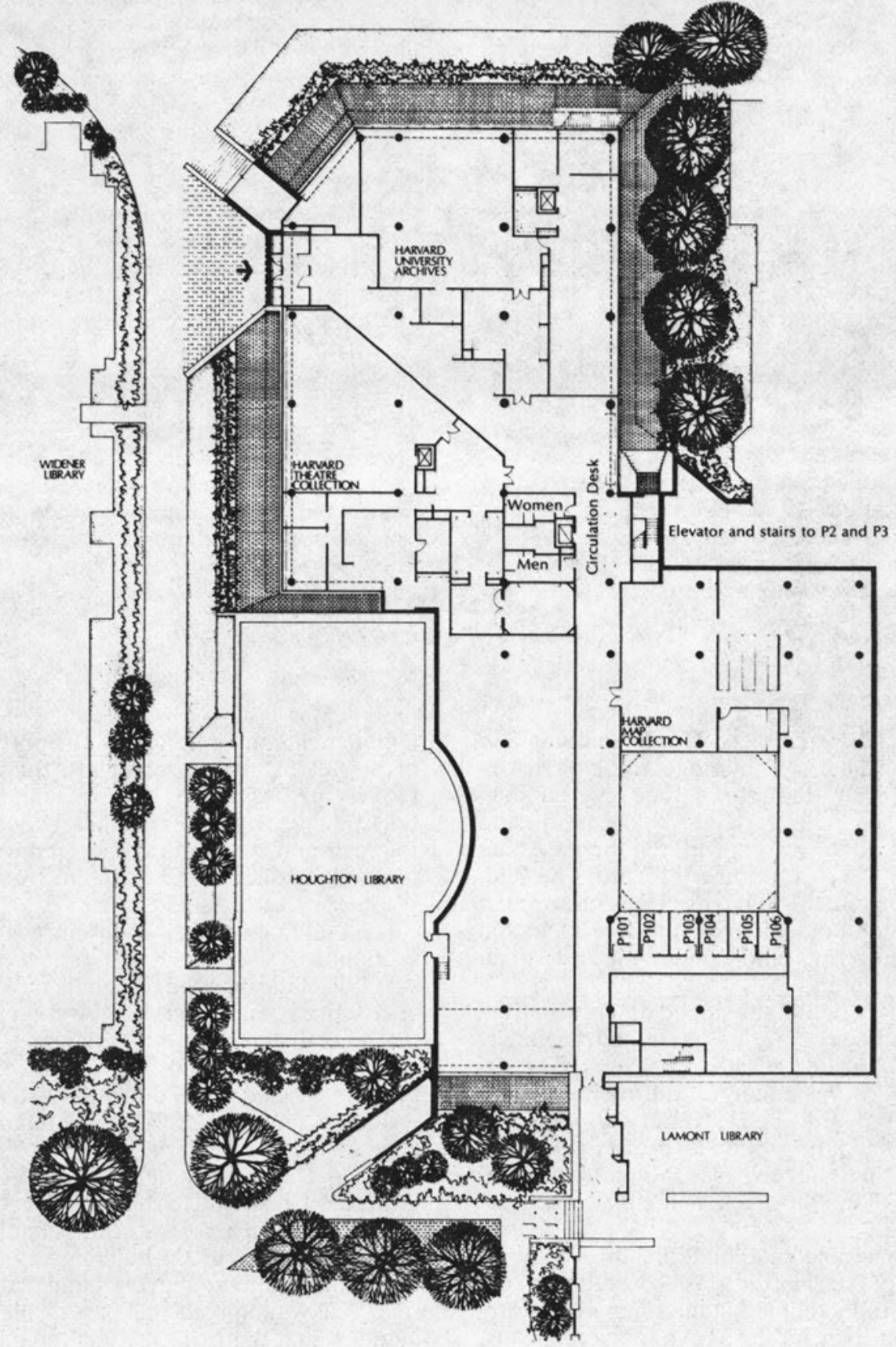

Pusey Library at Harvard: Floor plan of the upper level, showing how the library is placed between Widener, Houghton, and Lamont Libraries. 


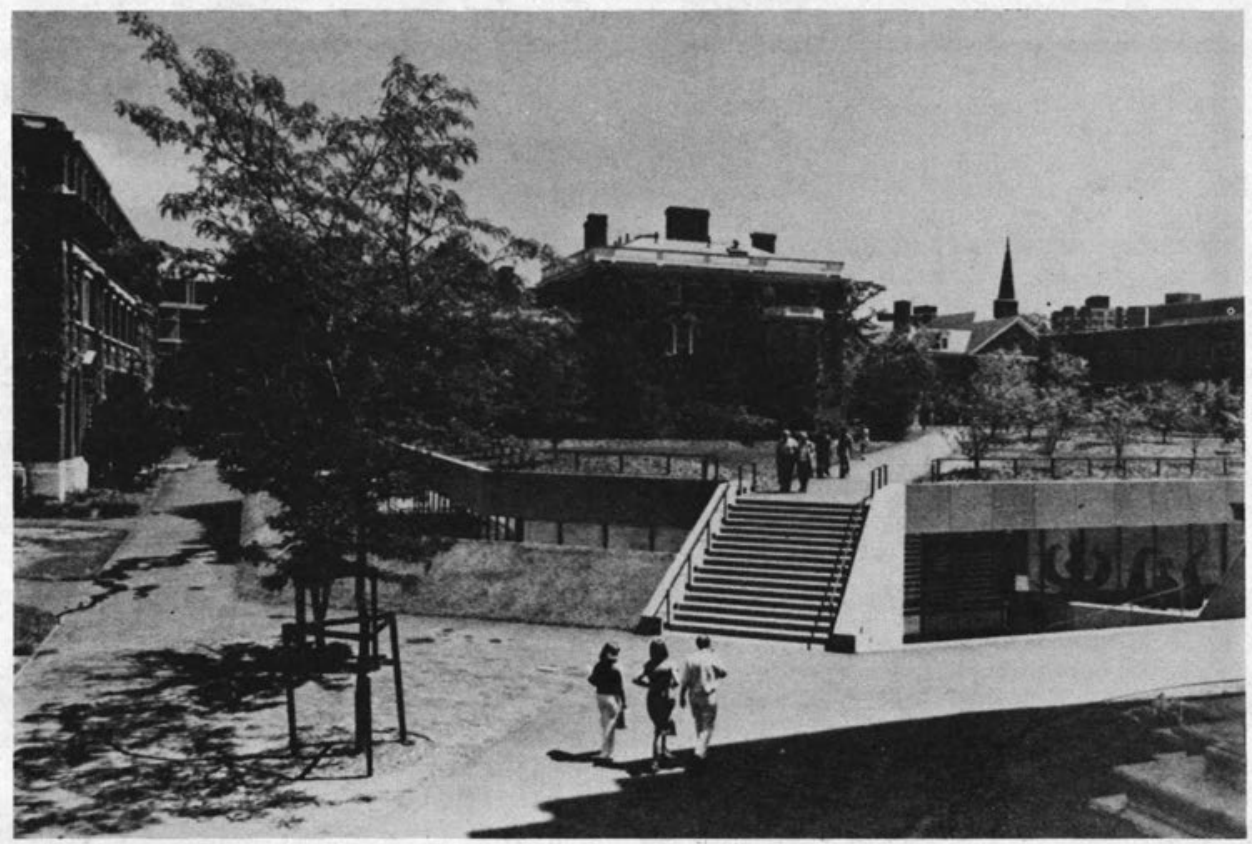

Pusey Library at Harvard: By placing the library below grade the buildings surrounding Harvard Yard remain unobstructed. (Photo: E. J. Jacoby).

est. The architects, Hugh Stubbins and Associates of Cambridge, resolved this dilemma by designing a three-level building whose main parts are below grade and that interconnects with the three existing libraries surrounding the Yard: The Widener with its research materials; Houghton, which contains rare books and manuscripts; and Lamont, the undergraduate library.

The original site sloped downward from south to north and was crossed diagonally by a major pedestrian pathway. The design of the underground building maintained the pedestrian walkway but changed the ground level to a flat surface. This partially exposes the northwest corner of building, where the main entry occurs.

In visible exterior form, the Pusey Library is a slanting grass-covered embankment. Its roof is a stone-rimmed platform of earth including a lawn, flowering trees, and shrubs. On axis with the NeoGeorgian bowfront of the Houghton is a square sunken courtyard, which admits light to major interior spaces. The portion of the building that appears above the surface is surrounded by a broad band of brick paving, which forms a moat between the berm and the window wall. At the top of the berm is a deep concrete trough planted with shrubs and vines.

The building's principal entrance is set at its northwest corner, adjacent to the east side of the massive brick bulk of Widener Library, and is reached by descending several steps. The walls flanking the steps repeat the reddish gray Canadian granite, selected for all the visible exterior walls and stairways of the Pusey Library. Past Alexander Calder's black steel stabile, The Onion, heavy glass doors open into a brief vestibule to this main level. A major corridor, part of the principal public passageway through the building and corresponding with the above-ground pedestrian walkway, directs one past displays, lnunges, and the main reading rooms of the three special collections.

All the reading rooms and offices on this level have large windows facing the moat 
around the building or the central sunken courtyard. The larger stacks for the University Archives and manuscript stacks from the general collection occupy most of the second level. Located on this level are entrances to the three adjacent library buildings. Faculty studies are found on three sides of the central courtyard. The lowest level, about half the area of the upper two levels, contains more stacks of the general collection. The building is 87,000 square feet.

The decision to place the Pusey Library underground presented a number of obstacles. The water table is very near the surface and melting snow or heavy rains can cause flooding. To prevent this, a grid of perforated drainpipes was laid beneath the foundation slab, behind the buried walls and on the earth-covered roof. Any water seeping into this zone near the building is drained by four sump pumps. All building surfaces are waterproofed with a mastic coating, neoprene, or both. The entire building is protected from fire by a system using tanks of liquid halon stored under pressure and released as a gas in the precise amount needed to extinguish the fire.

The need to protect the contents of the structure resulted in a variety of unusual measures being taken. For example, all fluorescent lighting fixtures are covered with ultraviolet shields to protect the materials from deterioration. Windows are triple glazed to aid in the careful control of humidity. The subsurface design also contributes to the security of the building, with limited, well-controlled points of access. Sound reduction is another benefit of underground space.

Built at a time when energy conservation was not a major concern, the level of energy consumption, because of the unusual climate control requirements, appears high. In large portions of the building, interior temperature is maintained at seventy degrees Farenheit and relative humidity at 50 percent year-round. But because of the large mass and reduced infiltration of the underground structure, the system can be shut off without affecting humidity or temperature for as much as eight hours or longer and, conse- quently, operates only about fifteen hours per day. As a result, the energy consumption is less than predicted in the planning stage: electrical use was expected to be twice and steam use five times as much.

Pusey Library and its designer have received an award for architectural excellence from the American Institute of Architects and the American Library Association for the successful union of function and form.

In 1976, another library with a capacity of 100,000 volumes was built below grade at the University of California at San Diego in La Jolla. ${ }^{15}$ The library of Scripps Institute of Oceanography was set into a hillside, cropping out to the leeward.

For a long time, the Avery Memorial Architectural Library, one of the great libraries of architecture, suffered from lack of space. Established as a branch of Columbia College Library in New York in 1890 , it acquired in 1912 a proud building of its own. Avery Hall, a four-story NeoRenaissance palazzo, was designed by Charles McKim, of the great firm of McKim, Mead, and White, who had also provided the master plan for the new campus of Columbia University. Because of the lack of campus space and the need to preserve Avery Hall, Alexander Kouzmanoff, chairman of design at Columbia's School of Architecture, in 1977 followed the examples of Harvard and Yale and solved the complex task of extension by going underground beneath the central portion of Fayeweather Court. ${ }^{16}$

On a lower level, the 80 -by-150-foot construction provides a large and small auditorium, classrooms, and wide exhibition spaces for the School of Architecture and, on the upper level, a new reading room and reference-service area for the library of Architecture and Fine Arts. These levels are connected to the old Avery building by separate staircases: directly to the old McKim Reading Room on one level, and to the elevator lobby of the School of Architecture on the other. Under a skylight, the grand stair between the old and the new reading rooms achieves a particularly dramatic opening of a classical space into a modern one. The basement level of the old Avery building is now fully open toward 
the new rooms. Together with the new building, the completely remodeled old one forms a preeminent research institution for the whole subject field.

The year 1980 appears to be the first year a public library was constructed below grade. Located at a busy intersection in a south Minneapolis commercial center, the Walker Community Library is a satellite facility serving the immediate neighborhood. ${ }^{17}$ The 18,500 -square-foot structure contains a large reading room with a medium-sized book collection and a public meeting room that serves a variety of community groups. The almost completely subsurface design resulted from a combination of site-related factors and the desire to take advantage of the sound reduction and energy-conserving benefits of underground space. An important factor in the decision to place the library below grade-besides the limited size of the 20,000-square-foot site-was the desire to create a community resource on the site. A small, urban plaza on the roof of the struc- ture was created to provide space for neighborhood activities. Additional roof space provides necessary parking.

To define the edges of the building and to direct people to the entrance, planters, walls, and other above-grade elements were necessary. The street-level entrance, mechanical equipment, and an elevator shaft are designed as a small grouping of above-grade concrete forms. Because the main occupied spaces in this building are completely underground, the small sunken courtyard becomes important for natural light and view. A single large window in the lower-level reading room faces the courtyard. A large adjacent mirror is set at forty-five degrees from the wall to reflect light into the room and to create the illusion of looking out from nearly any point in the room.

The interior space of the reading room is, at about twenty feet, relatively high. An open grid suspended from the ceiling contains light fixtures and heating equipment. The designers estimate that the de-

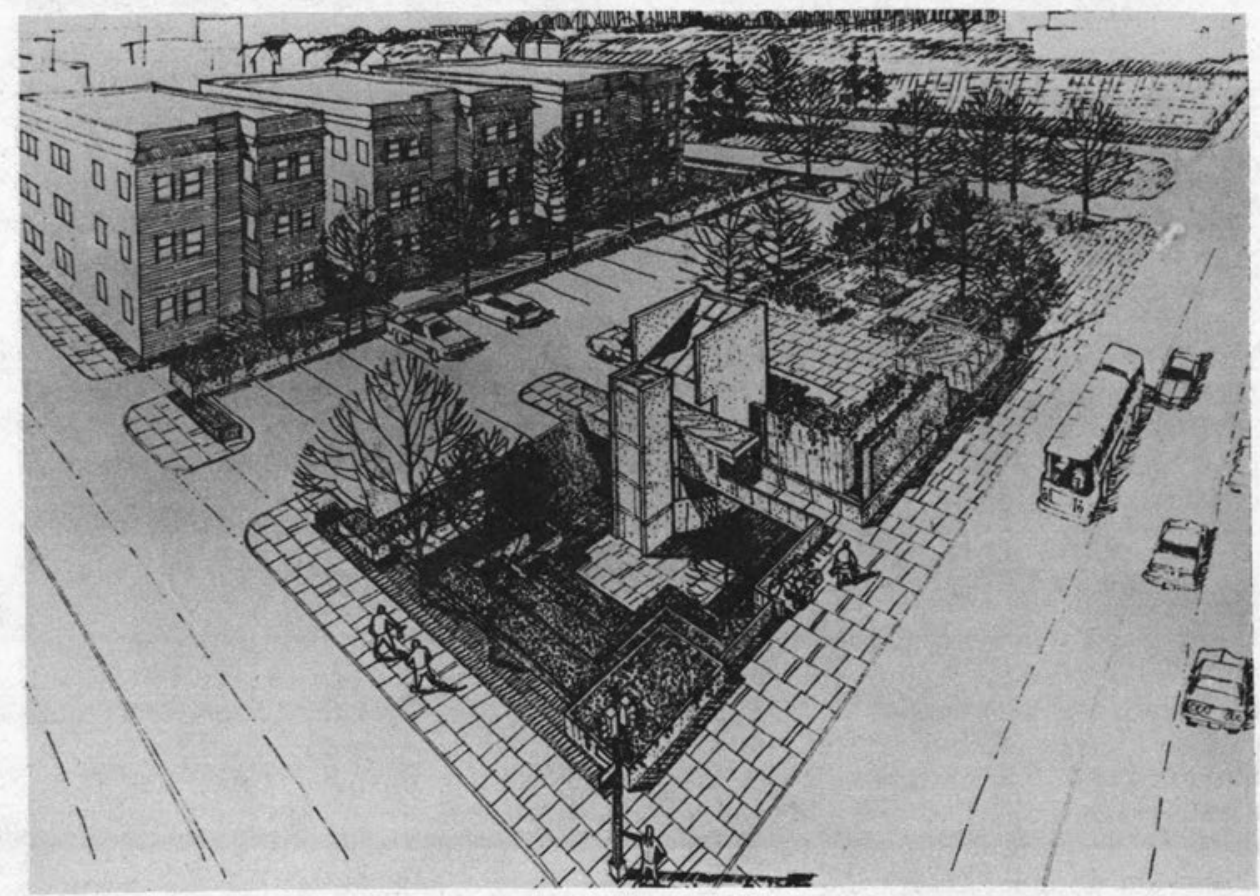

Walker Community Library in Minneapolis: View of the entrance, the plaza at right, the sunken court at left. (Photo: P. Siegrist). 
mand for heating and cooling will be reduced by 40 percent compared with a conventional above-grade building. A heat recovery system reduces the energy used to heat and cool outside air for ventilation, and insulating shutters are rolled down over the windows at night. In addition, the hard surfaces on the roof are shaded by plant materials and vines hanging from trellis structures supported by light fixtures for the parking area. The level below grade contains the 150 -seat community meeting room. Together with the library and the plaza, this is a very attractive location for neighborhood activities.

Undoubtedly one of the most striking libraries built underground is the Law Library Addition at the University of Michigan, Ann Arbor, opened in $1981 .{ }^{18}$ It is a remarkable example of the potential for providing natural light, a view, and dramatic interior spaces underground. The structure was designed by the architectural firm of Gunnar Birkerts and Associates of Birmingham, Michigan. The master plan for the law school, which occupies an entire city block, had been completed

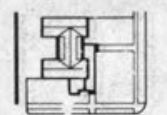

Law Library Addition, University of Michigan, Ann Arbor: Site plan of the Law Quadrangle.

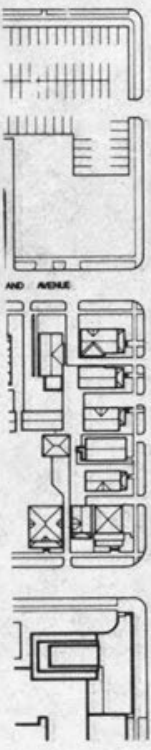

in its final form except for the southeastern corner. The buildings were designed in Neo-Gothic style, and constructed between 1924 and 1933. The corner was designated as the site for the proposed Law Library Addition. However, the architect felt that a structure placed in the open area next to the older library building would shift the balance of the entire complex. A completely underground design was the only solution to achieve both compatibility with historic buildings and preservation of open space and views on the Lshaped site.

Three L-shaped levels with a total of 77,000 square feet were placed completely beneath the surface. The architect flooded the three underground levels with daylight by placing a 150-by-26-foot sloping skylight within a V-shaped moat and a smaller triangular well. A sloping limestone wall and a series of mirror mullions permit light to enter levels that are set back from the light well and form balconies overlooking multistory spaces. Natural light is available in most areas of the building. At night, the skylights permit views of the lighted interior. Entrance to the un-
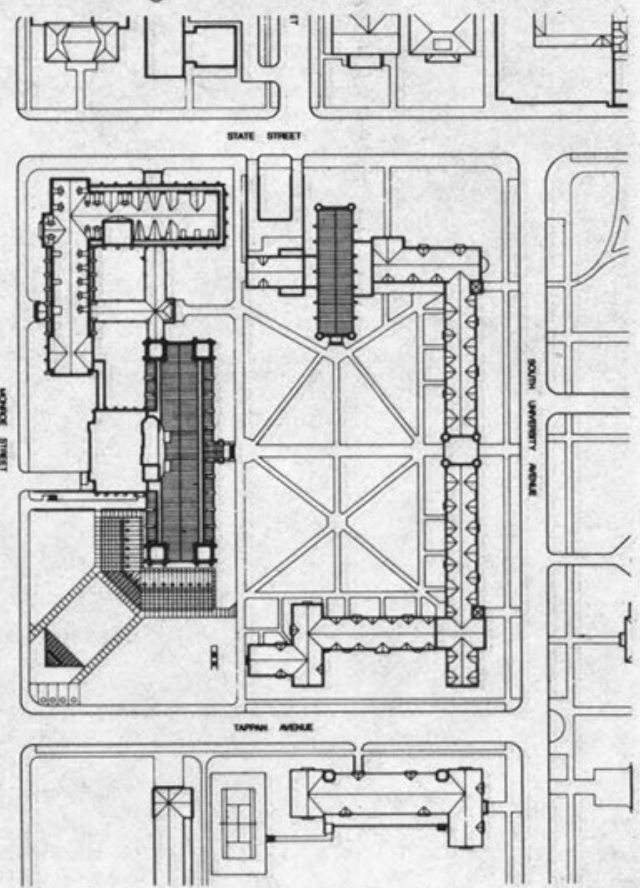
derground facility is through a pleasing direct stairway from the old library to the upper underground level. On this level are the catalogs, a circulation desk, and reading rooms; the other two rooms contain mainly book stacks. An open grand

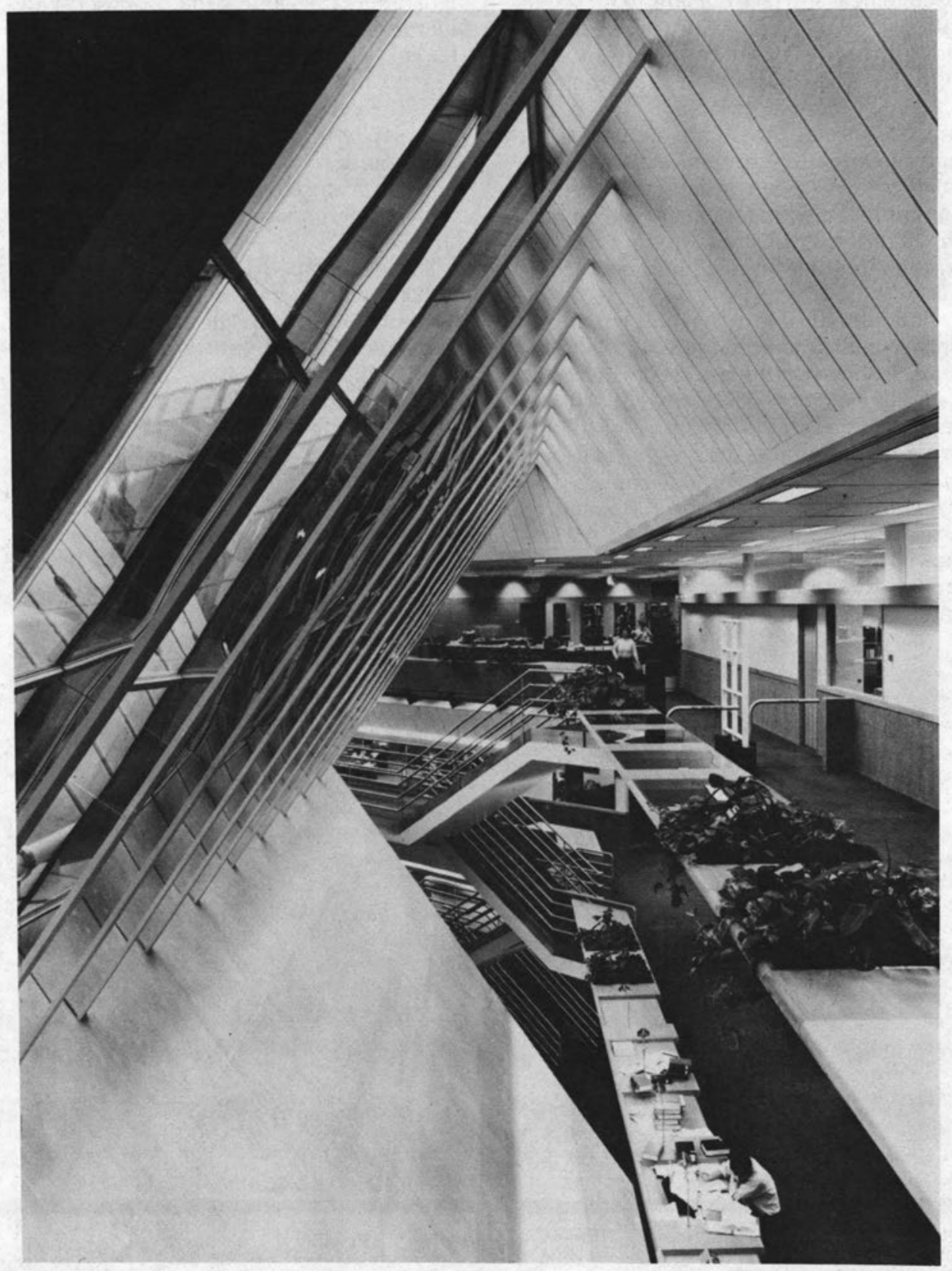

Law Library Addition, University of Michigan, Ann Arbor: A series of mirror mullions at left permit light to enter all levels which form balconies overlooking the light well. 
Law Library Addition, University of Michigan, Ann Arbor: Floor plan of the upper underground level with a direct stairway from the old library.

stairway in the center of the light-well area is designed as an elaborate suspended form. The building is designed to accommodate 500 readers and to house about 500,000 volumes.

Because of its below-grade placement and relatively small total glass area, the building envelope is inherently energy conserving. Efficient, air-return parabolic luminaries are used for general lighting, and fixtures near the light wells have photocell controls that automatically turn lights off when an adequate level of natural light is available. Nevertheless, the energy consumption is high because of the extended sixteen hours of operation per day. The sloping light well is supported by vertical concrete piles forming a retaining wall to protect the existing foundation of the adjacent older building.

With the experience of Ann Arbor behind him, architect Gunnar Birkerts designed one more underground library. In September 1982, the Uris Undergraduate Library of Cornell University, Ithaca, New York, opened an underground extension of the old building. ${ }^{19}$ For reasons of security and to avoid wear and tear that would result from through traffic, the addition is accessible only through the old structure. No separate entrance exists.

The stairway connecting the two buildings is enclosed in glass and provides a panoramic view of the valley below and the landscaped surroundings, thus transforming a potentially negative descent into an unusual spatial experience. Much emphasis is placed on the design of the connection between the above- and below-grade buildings. The addition is essentially a reading room with no shelving space for books. There is no staff working space, except for a monitoring station at one end of the room. The underground addition has a total of 214 seats, including 15 in three group-study rooms of 5 seats each. The addition satisfies the longstanding need for more study space in Uris Library and, therefore, has been very popular with students who use it heavily.

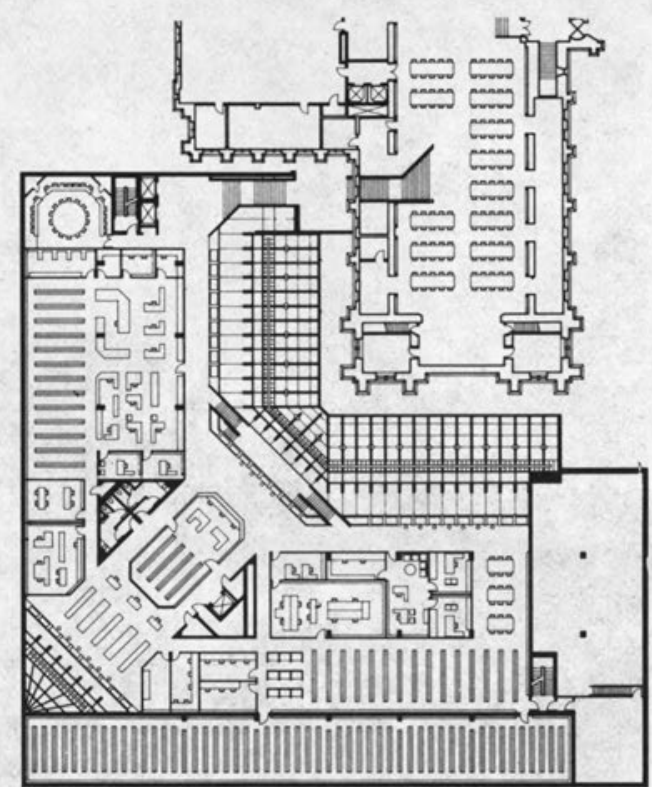

It has become the most popular reading room in the library.

Early in 1983, the archabbey of Saint Meinrad, Indiana, opened a muchneeded new academic library building. ${ }^{20}$ The library is a part of the new building program for the monastery. Designed by the architectural firm of Woollen, Molzan and Partners, Indianapolis, the plan aimed at replacing and upgrading older facilities. Some of the buildings date from the 1850 s when a mission of Benedictines from the home abbey in Einsiedeln, Switzerland, following a wave of Swiss and Bavarian immigrants, crowned a hilltop in southwestern Indiana with a Neo-Gothic church and monastery.

The new library is to serve the college, the theology school, and the monastery as a research and study facility. Because of the topography of the site, and in order to leave the remaining nineteenth-century buildings undisturbed, the library is angled into a hollow at the foot of the hill below the main entry to the school. The land surrounding the trilevel building, whose entry is at the top floor, is a terraced slope planted as a garden. The terrace theme is carried forward by a grass-covered, bermed roof and garden beds alternating 


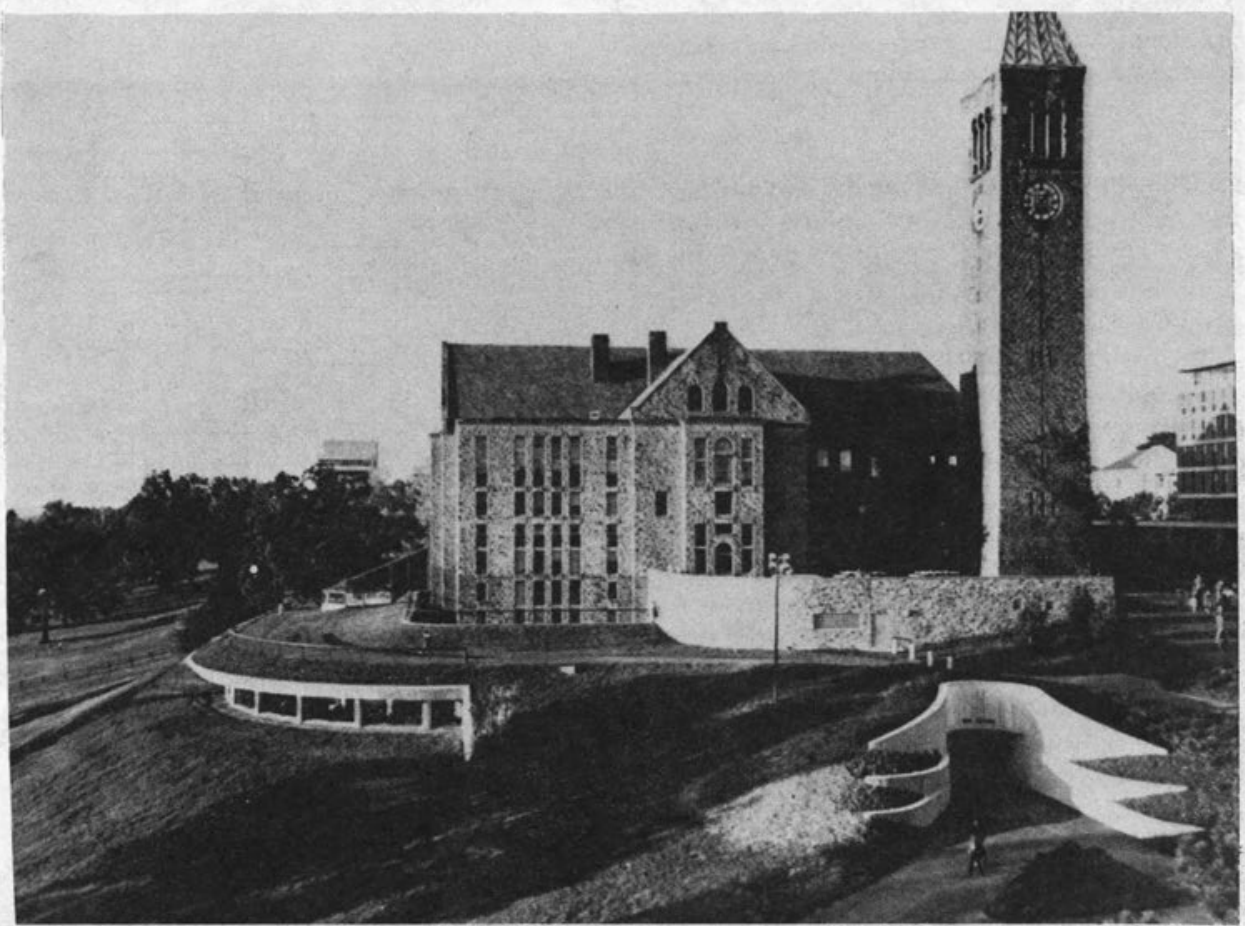

Uris Undergraduate Library at Cornell University: The addition to the old library is placed in a sloping site and provides panoramic view of the valley and surrounding. (Photo: T. Hursley).

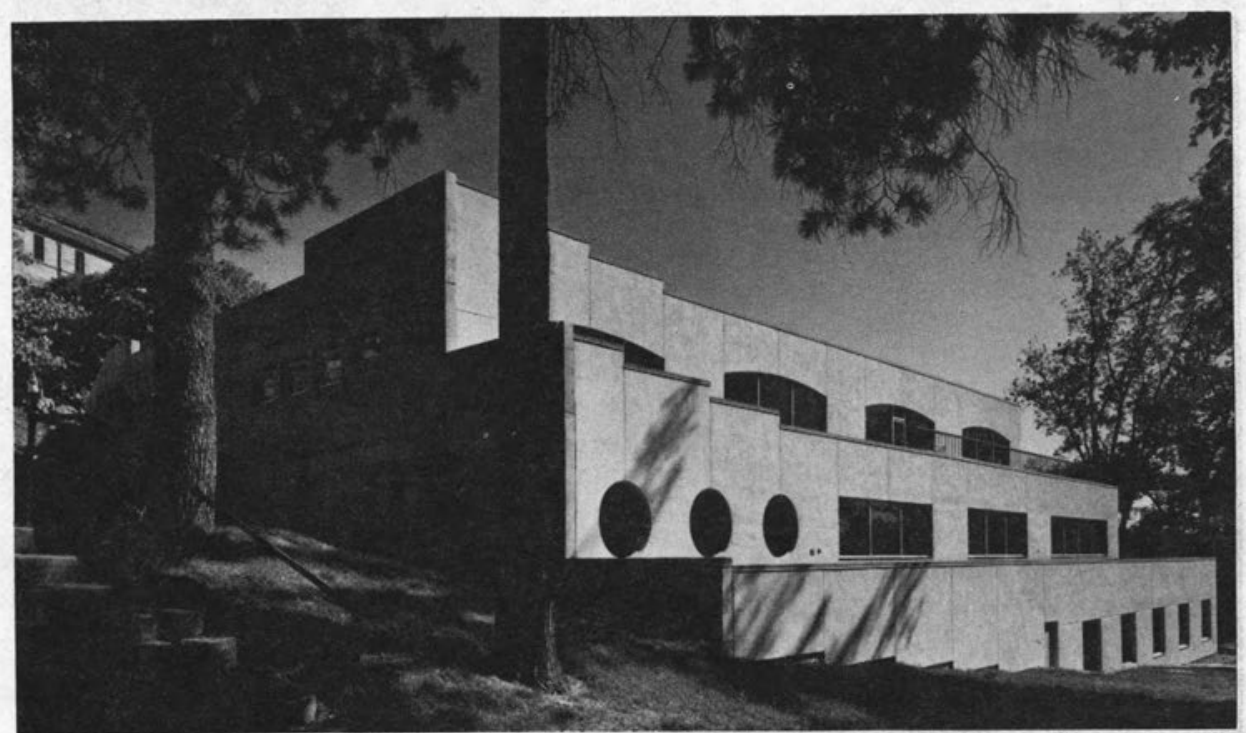

Saint Meinrad Archabbey Library: The library is conceived as a retiring building of terraces stepping down a steep slope. (Photo: B. Korab, Troy, Michigan). 


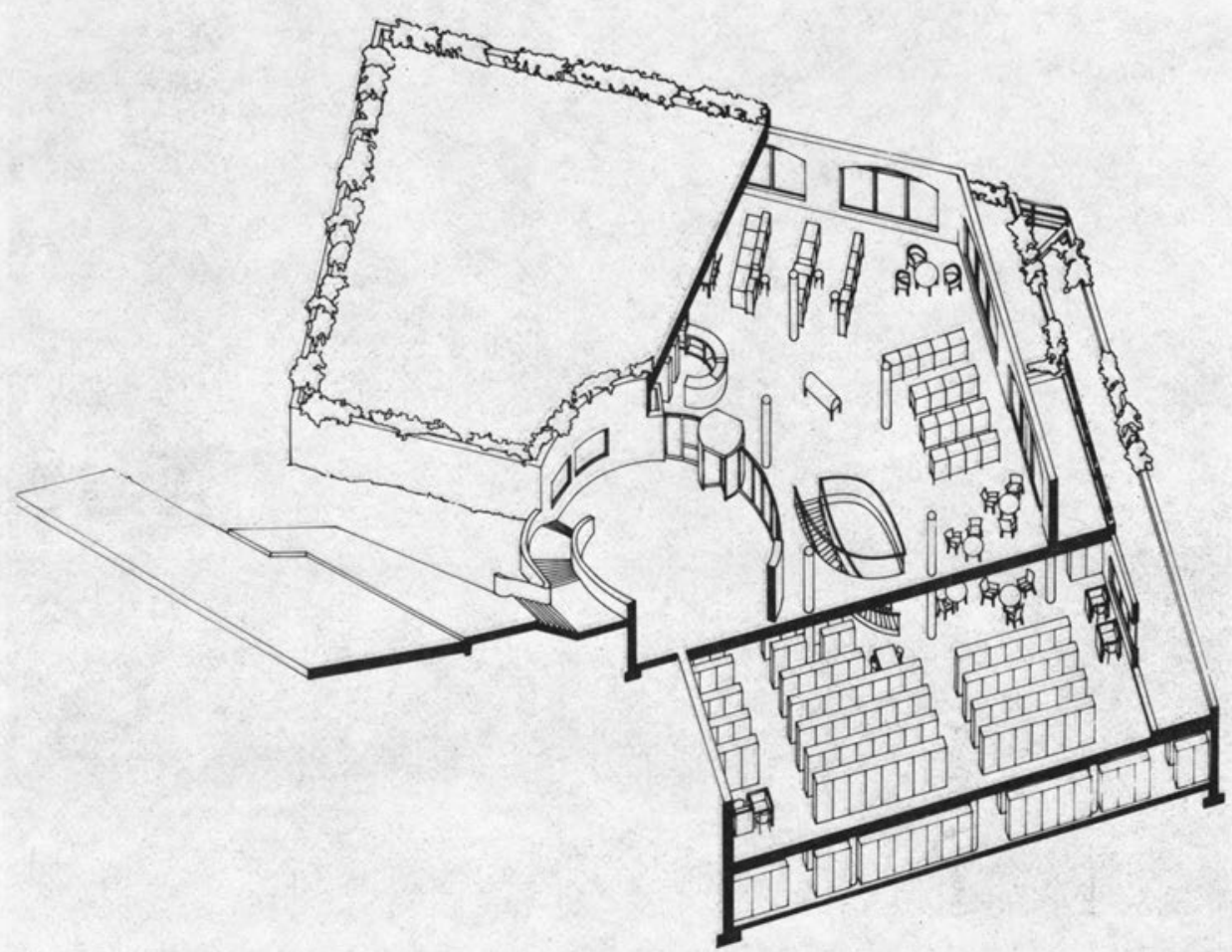

Saint Meinrad Archabbey Library: Isometric view of the library through to the lower level.

with tile-paved seating on the decks of the lower levels. When the planting matures, the building will be draped in ivy. From the major pedestrian path of the archabbey, a double-ramped, descending staircase leads to the main entrance through a circular courtyard. Located on the entry level are the circulation functions and all staff offices. These are connected by a curving staircase, which leads to the more concentrated collections with carrels near the windows and small-group study spaces on the floor below. The lowest level is devoted to archival materials and technical service areas. The 39,000 square feet of assignable space provides room for 200,000 volumes, and 152 reading places.

The new public library in Vail, Colorado, was dedicated in July 1983 . Designed by the architects Snowdon and Hopkins of Vail, the building is recessed into a slope that permits a southeast exposure looking out on the confluence of Middle and Gore creeks. The 16,375-square- foot structure has a post-tensioned concrete roof that has been covered with soil. This earth-sheltered design was created for heat efficiency in a snowy climate and to achieve minimal visual impact. $\mathrm{Na}$ tive stone and redwood were used on the exposed parts of the building. The entire length of the north/south entry corridor is a skylight that provides a dramatic and spacious entrance for the library and the community rooms that are available for use when the library is closed. The building will accommodate 60,000 volumes and seat ninety in the library, sixty in the community rooms, and fifteen in a multipurpose room. This latter room is enclosed in glass block and fitted with heavy drapes to darken it for screening movies or watching videocassettes. The staff and users are very pleased with the library, which received the 1985 Award of Excellence for $\mathrm{Li}$ brary Architecture in the eleventh Library Buildings Award Program sponsored jointly by the American Institute of Archi- 


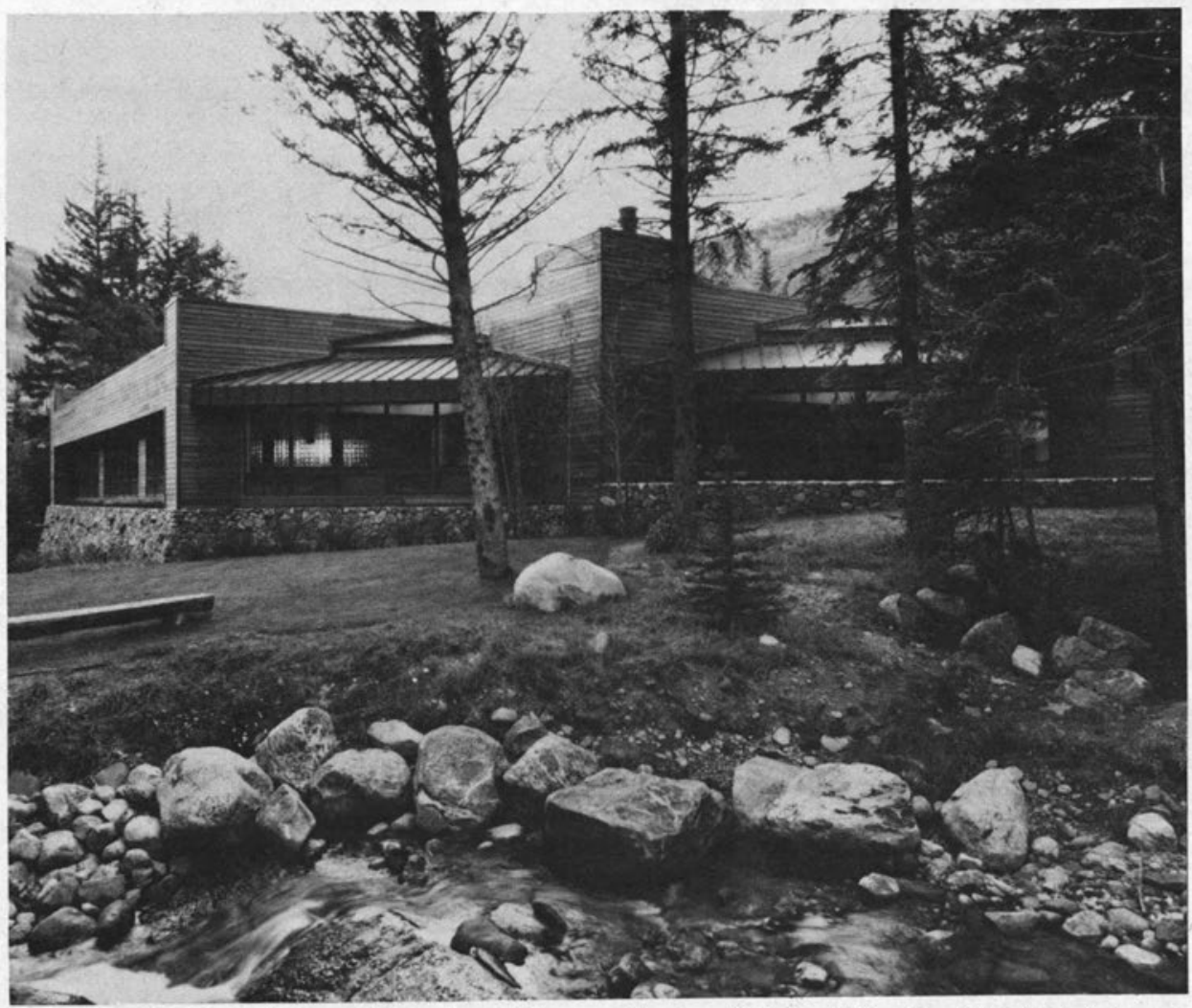

The Vail Public Library is recessed into a slope with a grass-lawn roof. (Photo: T. Hursley, Little Rock, Arkansas).

tects and the American Library Association.

South Africa's first underground library was opened in January 1984, in Stellenbosch, the country's oldest town, founded in 1679 in the mountainous western Cape. ${ }^{21}$ The University of Stellenbosch Library, founded in 1866, replaced the old Carnegie Library building and centralized most library activities that had been spread across the campus. Architects' research had shown that a building on that site would not be compatible with the scale of the university square and the surrounding low-rise buildings. The decision was made to go beneath the historic Jan $\mathrm{H}$. Marais Square, located close to most of the University's academic and administrative buildings. The new J. S. Gericke Library houses approximately 500,000 volumes with enough space for an additional
500,000 . There are 1,663 seats for the roughly 12,000 users who are served by 110 staff members. With 180,000 square feet on two levels, the Gericke Library appears to be the largest underground library in the world.

The approximately 100,000 -square-foot roof has been planned to retain the pedestrian "desire lines" and to give life to an otherwise barren landscape. The south of the roof opens into a trough, terraced by wide stairways descending to the main entrance on the upper level. Natural light is admitted from this side into the reading areas. The interior design facilitates orientation through a system of major and minor routes. Much emphasis is placed on spaciousness and flexibility, with skylights illuminating the main circulation ramp. Designed on a totally modular ( 25 by 25 foot) plan, the building is fully air- 
conditioned and humidity controlled. Special attention has been paid to the acoustic treatment of the study areas. The building is waterproofed with a prefabricated membrane. Encapsulated in bituthane, the building has a water-resistant barrier of polyethylene and rubberized asphalt. No serious leakage in the construction has been experienced. The library provides a comfortable environment and user opinion is very favorable.

Opened in early 1985, the storage library of the Swiss Federal Institute of Technology in Zurich is the newest and one of the largest underground libraries. ${ }^{22}$ The facility is located in downtown Zurich because the Polytechnic had no space left for expansion of its famous University Library designed by Gottfried Semper. In recent years, some library departments had been dislocated at the new campus on the Honggerberg, a hillside on the outskirts of the city. There, a sloping site was made available for the approximately 65,000 square-foot structure placed underground to preserve the landscape and to protect books and other property of cultural value from war damage or natural catastrophe. There are 49,000 square feet of assignable space, of which 4,000 square feet are devoted to patent specifications, 38,500 for little-used books, 4,800 for other items of cultural value and 1,600 for staff work rooms and a small reading room looking out on the hillside. Mobile stacks of compact shelving house $3,000,000$ volumes.

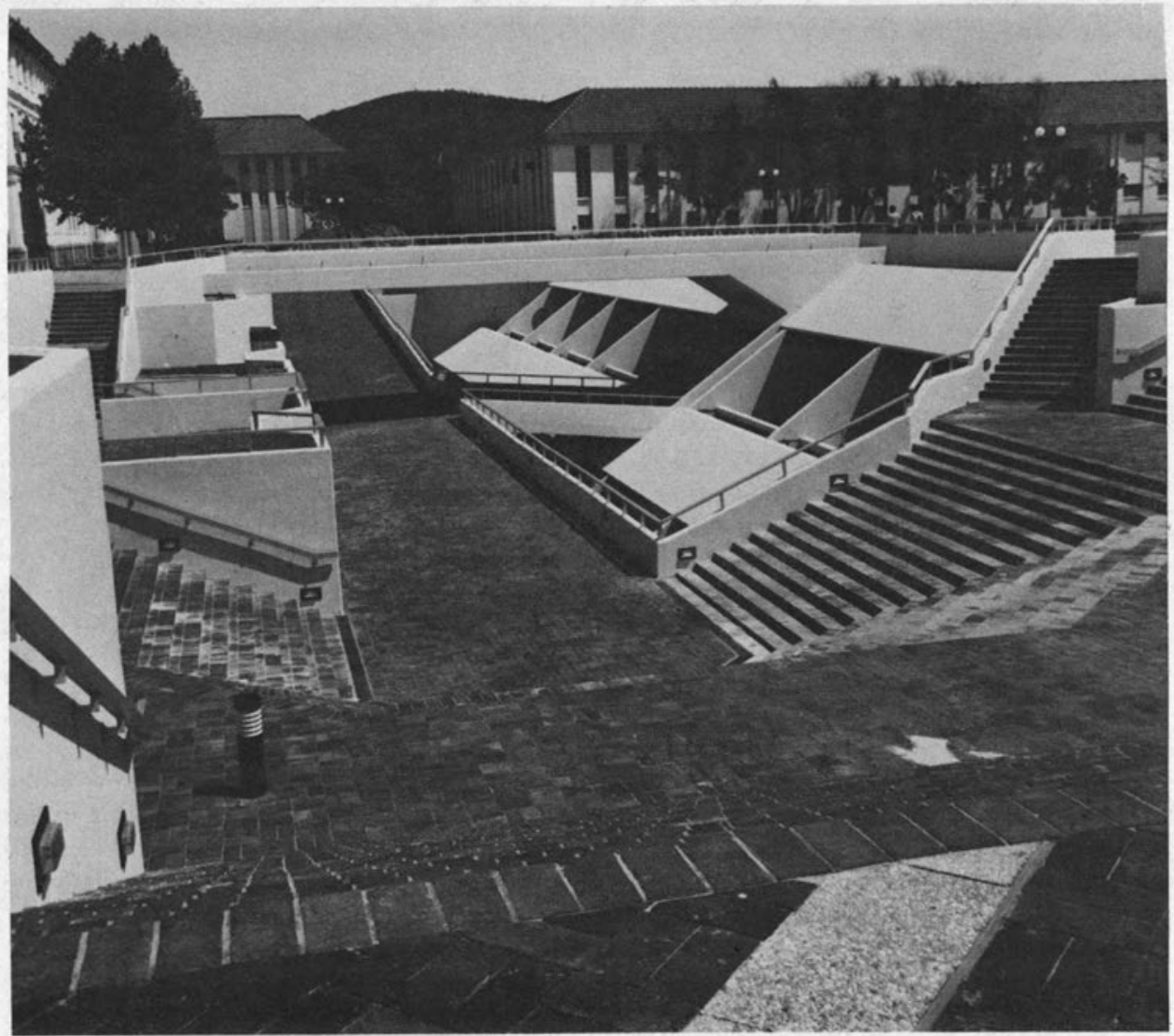

Gericke Library, University of Stellenbosch, South Africa: Natural light is admitted from the south into the reading areas by opening up the square at the entrance to the library. 


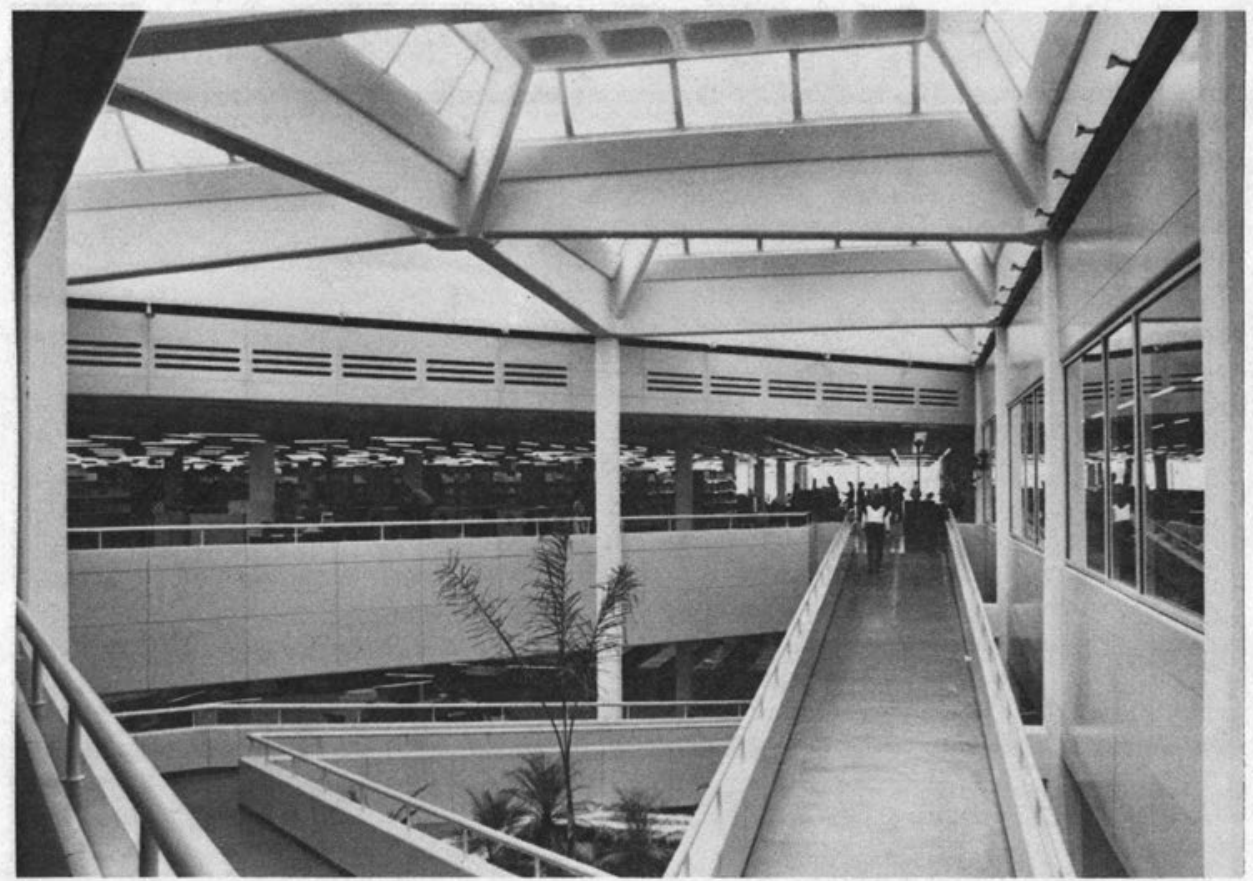

Gericke Library, University of Stellenbosch, South Africa: Visual emphasis is placed on the main circulation ramp in the atrium connecting both underground levels. (Photo: J. Stande, Stellenbosch).

The site provides the possibility for an underground addition of the same size. The two-story structural system is designed to support three above-ground stories as a further extension. For delivery of books and goods, the above-grade entrance is provided with a loading ramp and a lift.

\section{CONCLUSIONS}

These examples demonstrate the emergence in the past two decades of a new architectural trend. Underground architecture is a marriage of building and the natural environment quite unlike any other design movement of the twentieth century. Although subsurface construction is not new to history, it is new to architecture and landscape architecture and very new to library practice. Currently, there are twenty-two underground libraries, most of them in the United States, and some have received architectural awards.
The first underground library buildings have not experienced greater problems than above-ground structures. In fact, surprisingly few problems have been encountered. No more water comes into them than come through skylights or flat roofs on above-grade structures. Constructions beneath the water table are designed as concrete boats and careful insulation and drainage prevent any water seepage. Sunken courts sometimes omit that careful waterproofing. Air conditioning and humidity control can be maintained better underground than above ground because the extremes of day-night or seasonal temperature swings are absent. One problem common to all underground libraries is how to bring natural light down into their interiors. For the most part, this constraint is overcome through the use of sunken courts and other openings to the surface. In most library buildings, this problem has been solved satisfactorily. A great problem to 
architects is to identify the entrance from the exterior. More experience with designing for underground use will refine and identify options. The coming years will be challenging to architects and librarians.
Underground libraries may be one solution to the space problem of our libraries in our overcrowded and overurbanized environment.

\section{REFERENCES}

1. Lester L. Boyer, ed., Earth Shelter Performance and Evaluation (Stillwater, Okla.: Oklahoma State Univ., 1981); John Carmody and Raymond Sterling, Underground Building Design: Commercial and Institutional Structures (New York, N.Y.: Van Nostrand, 1983).

2. Ralph E. Ellsworth, Academic Library Buildings (Boulder, Colo.: Colorado Assn., Univ. Pr., 1973); Rolf Fuhlrott, "Bibliotheken und der Erde" [Libraries below Grade], ABI-Technik 5, no. 1:1-13(1985); David Kaser, "Twenty-five Years of Academic Library Building Planning," College \& Research Libraries 45:269-81 (July 1984).

3. Allen Kent and others, eds., Encyclopedia of Library and Information Science, V.1-38 (New York, N.Y.: Basel, Dekker, 1968-1985); Kenneth Labs, "The Architectural Underground History," Underground Space 1:1-8 (May/June 1976); 1:135-56 (July/Aug. 1976); Kenneth Labs, "Terratecture: The Underground Design Movements of the 1970s," Landscape Architecture 67:244-49 (May 1977); Frank L. Moreland, ed., Earth Covered Buildings and Settlements (Springfield, Va.: National Technical Information Service, 1979); Raymond L. Sterling and others, "Energy and Earth Sheltering Revisited," American Institute of Architects Journal 72:48-73 (Jan. 1983); Henry Stierlin, "L'Architecture Souterraine" [Underground Architecture], Werk 62:878-92 (Oct. 1975).

4. Franz Kroller, "John M. Olin Library, Washington University, St. Louis," Bauforum 3, no. 17:15 (1970); Ellsworth, ibid., p.xvii, 59, 159, 196, 430, 509.

5. The Beinecke Rare Book and Manuscript Library: A Guide to its Collection (New Haven: Yale Univ. Library, 1974); Ellsworth Mason, "The Beinecke Library at Yale," Ellsworth Mason, Mason on Library Buildings (Metuchen, N.J.: Scarecrow, 1980) p.63-89. (Expanded version of article in College $\mathcal{E}$ Research Libraries 26:199-212, May 1965); Merrily E. Taylor, "The Beinecke Rare Book and Manuscript Library," Allen Kent, ibid., 33:282-86 (1982).

6. John H. Berthel, "Johns Hopkins Digs Down," Library Journal 89 (Dec. 1964); Ellsworth, ibid., p.39, 58, 191.

7. George E. Patton, "Lawn Tops Library's Growth in Bristol," Landscape Architecture 58:220-21 (Apr. 1968); Kenneth Labs, "Terratecture," ibid., p.247.

8. Frances Nix, "Indian Mound or Library? Berm Architecture Used to Store Treasures," Arkansas Libraries 24:9 (1968); Hendrix Burrows under Its Mall," College Management, Portfolio no.4, p.70-71 (Oct. 1968); James E. Lester, Hendrix College: A Centennial History (Conway, Ark.: Hendrix College, 1984); Kaser, ibid., p.278-79.

9. "UCLA: Research under the Lawn," College Management, Portfolio no.3, p.69 (Oct. 1968).

10. Karen Rugen, "More than a House of Books," American Libraries 2:876-81 (Sept. 1971); Lucien White, James Scheeler, Robert A. Miller, "Undergraduate Library, University of Illinois at Urbana," Library Buildings: Innovation for Changing Needs (Chicago: American Library Assn., 1972) p.119-32; Ellsworth, ibid., p.22, 35, 56, 57, 188, 286; Kaser, ibid., p. 280.

11. "New Yale Cross Campus Library Opened," Connecticut Libraries, Special Issue on Library Surveys, p.32-34 (Spring 1971); Merrily E. Taylor, "The Cross Campus Library: An Intensive-use Library, Allen Kent, ibid., 33:288-90 (1982).

12. "Sedgewick-Bibliothek, University of British Columbia," Baumeister 70:1265-69 (Nov. 1973); "Understatement: University of British Columbia, Vancouver," Progressive Architecture 54:86-91 (Mar. 1973); "Sedgewick Library," Architectural Review 160, no.954:69-71, (Aug. 1976). William Watson, "University of British Columbia: The Decision to Build an Underground Addition, "Running Out of Space. What Are the Alternatives? (Chicago: American Library Assn. 1978) p.102-06; Ellsworth Mason, "The Sedgewick Undergraduate Library at the University of British Columbia," Ellsworth Mason, Mason on Library Buildings (Metuchen, N.J.: Scarecrow, 1980) p.224-46. (Expanded version of article in Journal of Academic Librarianship 2:286-92 (Jan. 1977).

13. "Radcliffe Science Library," Building p.47-54 (Aug. 27, 1976).

14. Rene Kuhn Bryant, Change and Continuity in the Harvard Yard: The Nathan Marsh Pusey Library (Cambridge, Mass.: Harvard College Library, 1976); Mildred F. Schmertz, "In Defence to the En- 
vironment: The Pusey Library Was Built beneath Harvard Yard," Architectural Record 160:97-102 (Sept. 1976); "'Hiding out in Harvard Yard," Interior Design 47:144-46 (Dec. 1976). "Harvard's Underground Understatement," American Libraries p.114-16 (Mar. 1977); "Nathan Marsh Pusey Library," Carmody and Sterling, ibid., p.60-67.

15. Kaser, ibid., p. 279.

16. Adolf K. Placzek, "The New Avery Architectural and Fine Arts Library," Columbia Library Columns 27:23-31 (Feb. 1978); Suzanne Stephens, "Beneath the Halls of Ivy: Avery Library Extension, Columbia University, New York," Progressive Architecture 59:60-61 (Mar. 1978).

17. David J. Bennett, "Walker Community Library," Frank L. Moreland, ibid., p.230-40; "Walker Community Library," Carmody and Sterling, ibid., p.76-81.

18. Grace M. Anderson, "Architecture Beneath the Surface," Architectural Record 170:77-85 (Mar. 1982); M. J. Long, "Underground Book," Architect's Journal 176:24-30 (July 1982); "University of Michigan Law Library Addition," Architecture and Urbanism 142:21-33 (July 1982); "Erweiterung der Universitätsbibliothek in Ann Arbor, USA," [Addition to the University Library in Ann Arbor, USA] Baumeister 80:1063-67 (Nov. 1983).

19. Maria Cerruti, "Uris Library a Cornell Università," [Uris Library at Cornell University] Architettura, Cronache e Storia 29:864-68 (Dec. 1983).

20. Margaret Gaske, "Continuity amid Change: Saint Meinrad Archabbey Monastery and Library," Architectural Record 173:130-37 (Apr. 1985); Kaser, ibid., p.279.

21. "Underground Library, University of Stellenbosch," Architect \& Builder p.22-27 (July 1984).

22. Neubau eines Bibliotheksmagazins auf dem Hönggerberg. Eidgenössische Technische Hochschule Zürich [Planning of a Storage Library at Hönggerberg. Polytechnic Zürich] (Zürich: Office for Federal Constructions, 1980). 